\title{
The Ellipse and the Oval in the Design of Spanish Military Defence in the Eighteenth Century
}

\author{
Josep Lluis i Ginovart • Josep M. Toldrà Domingo • \\ Gerard Fortuny Anguera · Agustí Costa Jover • \\ Pau de Sola-Morales Serra
}

\begin{abstract}
The Spanish military engineers built several U-shaped strongholds during the eighteenth century, using the geometrical constructions of the ellipsis et ovum. In the project on paper, engineers used the oval because of its ease of layout, but they could use either of the two figures in the staking of the fortifications. In 1704 Vicente Tosca published a methodology for building infinite ovals from its main axes. The assessment of the staking of the artillery platform of San Jorge reveals that the trace can be based both on the ellipse as the oval shape, since they have negligible difference on the scale of construction. The ellipsis et ovum discussion had a linguistic aspect from the perspective of applied mathematics, since different geometrical approximations for these artillery platforms may converge.
\end{abstract}

Keywords Military architecture - Spanish military architecture · Fortifications century · Ellipse · Geometry · Oval

\footnotetext{
J. Lluis i Ginovart · J. M. Toldrà Domingo · G. Fortuny Anguera · A. Costa Jover (凹) · P. de Sola-Morales Serra ETSAR, Universitat Rovira i Virgili, Campus Bellissens, Av. Universitat, 1, 43204 Reus, Spain e-mail: agusti.costa@urv.cat

J. Lluis i Ginovart e-mail: josep.1luisg@urv.cat

J. M. Toldrà Domingo e-mail: jmtoldra@gmail.com

G. Fortuny Anguera

e-mail: gerard.fortuny@urv.cat

P. de Sola-Morales Serra

e-mail: pau.desolamorales@urv.cat
} 


\section{Abbreviations}

AGS Archivo General de Simancas

MPD Mapas, Planos y Dibujos

SHM Servicio Histórico Militar

\section{Introduction}

During the War of the Spanish Succession (1701-1713), Philip V (1683-1746) created the Royal Corps of Military Engineers (1711) and the Academy of Mathematics of Barcelona (1720), introducing Enlightenment thought to Spain. Earlier, the Habsburg dynasty had established the Academy of Mathematics, regulating the powers of the King's Engineers in Madrid (1582, 1612), followed by Brussels (1675) and Barcelona (1692).

The Spanish military treatises of the seventeenth and eighteenth century assume the universality conferred on mathematics by Cartesianism as a method for the investigation of reality, dealing with the causes and effects that perfect the world (León 1992). The engineer Diego Enrique de Villegas (d. 1651) defined military architecture as a science that teaches its students about all the possible types of siege, based on their strength or weakness. Its foundations lie in mathematics and it is one of the parts into which it is divided (De Villegas 1651: 5-9). The engineer Andrés Davila y Heredia (d. 1672) explained the hierarchy which some parts of Mathematics retain within the arts, and stated in (Davila 1672: 6-56) that arithmetic and geometry are the foundations for the others. Geometry is sovereign to such an extent that all its operations are considered for the use and success of the arts, because the architect is unable to work in any area without it. According to the engineer José Chafrión (1653-1698), speculative arithmetic considers the hidden properties of numbers and their practice and use (Chafrión 1693: 1).

Based on these assumptions, the Spanish military engineers of the eighteenth century built a series of U-shaped batteries acting as artillery platforms (Fig. 1). The classic discussion, ellipsis et ovum (Migliari 1995: 93-102), is a direct reference to the mathematical studies of conic sections, and their application in military architecture. The increased use of the string method for tracing the ellipse, as well as the dissemination of several methods for tracing ovals in the treatises on military
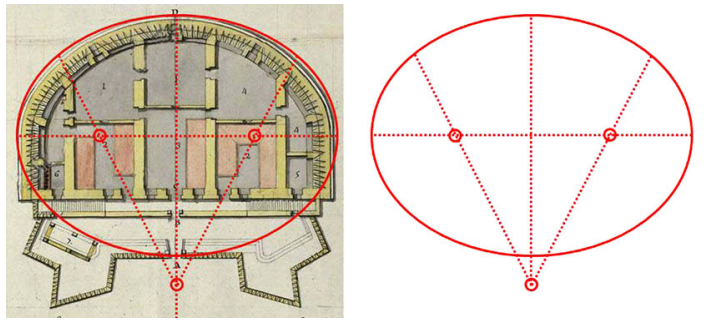

Fig. 1 U-shaped artillery platform by Pedro Moreau. Campo de Gibraltar (1750). Image: España, Miniesterio de Educación y Deporte, Archivo General de Simancas, ES.47161.AGS/4.3//MPD, 56, 038, with geometric overlay by the authors. Reproduced by permission 
architecture of the late sixteenth century, led to the discussion concerning the scale of one of these artillery platforms. The ellipsis et ovum discussion had a linguistic aspect from the perspective of applied mathematics. At the scale of construction, the geometric approach followed for defensive constructions- whether the ellipse and the oval—made a negligible difference.

\section{Non-Polygonal Defensive Bastions}

Defensive art is essentially based on polygonal shapes that can be constructed using triangular forms, depending on whether the fortification is regular or irregular. Military engineers in the eighteenth century used the U-shaped layout in some small coastal strongholds, such as Salobreña in Granada, 1722 (Fig. 2a) on the Alboran Sea, the Fort of El Ferrol on the Cantabrian Sea, 1731 (Fig. 2b) and the fortifications of Arrecife in Las Palmas in the Canary Islands, in the Atlantic, 1779 (Fig. 2c).

When laying out these fortifications, Bourbon engineers used either the measurements of the Castilian vara, as decreed by Philip II on 24 June 1568, or the toesa, decreed by Philip V on 4 July 1718, depending on the tradition they followed. The discrepancies between the work of some Spanish military engineers, and especially between the work in the Academy, where the vara was used, and standard practice, which used the toesa, led to the publication of a circular to the
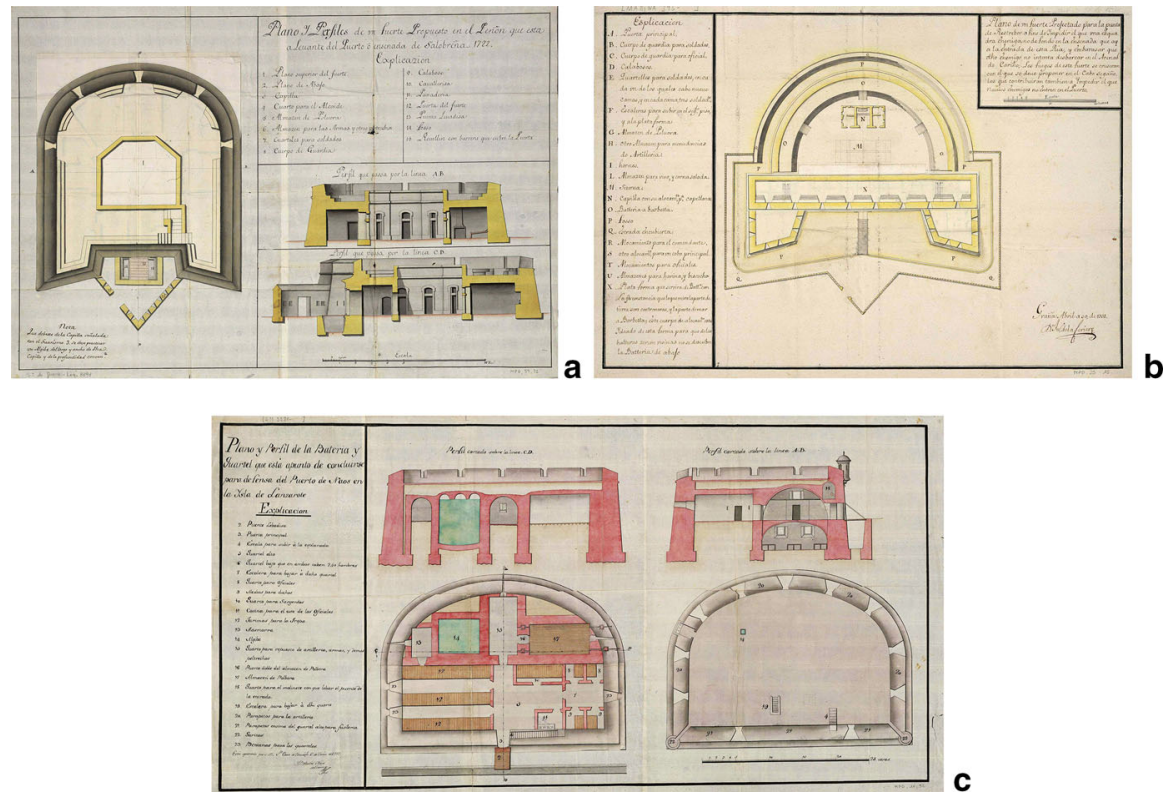

Fig. 2 Coastal Batteries: a Salobreña, 1722. Image: España, Miniesterio de Educación y Deporte, Archivo General de Simancas, ES.47161.AGS/4.3//MPD, 59, 032. Reproduced by permission, b El Ferrol, 1731. Image: España, Miniesterio de Educación y Deporte, Archivo General de Simancas, ES.47161.AGS/4.3//MPD, 25, 0159. Reproduced by permission, c Arrecife, 1779. Image: España, Miniesterio de Educación y Deporte, Archivo General de Simancas, ES.47161.AGS/4.3//MPD, 11, 052 
Captains General dated 14 July 1750 . This stated that not only would the Castilian vara be used in the teaching of mathematics, but that it would also be used in all matters relating to the Army and Navy. However, the Royal Order by Fernando VII dated 14 February 1751 stated that all military facilities had to use the toesa. The debate on the unit of measurement used in teaching at the Academy of Mathematics and in standard practice led its director, Juan Martin Zermeno, to reconsider the discrepancies between the use of the vara and the toesa in 1768 (Lucuze 1773: 3-57).

The debate focused on the military engineers' transfer of the project, which has a geometric structure, to an arithmetic metrology in the practice of fortification. The toesa used in the Tortosa region measured $194.90 \mathrm{~cm}$, and was subdivided into six pies (about $32.48 \mathrm{~cm}$ ). The Castilian vara, the length of which was equal to $83.59 \mathrm{~cm}$, was subdivided two ways: into four palmos (about $20.90 \mathrm{~cm}$ ) and into three pies (about $27.86 \mathrm{~cm}$ ).

The U-shaped layout appeared in the Principios de Fortificación written by Pedro de Lucuze (1692-1779) (1772) (Fig. 3), where it is described as the most common type occurring in the batteries in a fortress on the seashore, or the banks of a navigable river. The curvature of the bastion facilitates direct cannon shots in any direction. The entrance to the enclosure is located in the gullet or mouth of the $\mathrm{U}$, forming a small fortified front to defend the door from the flanks. The door is located in the middle of the retaining wall, and protected by a small pit (Lucuze 1772: 96-97, Fig. 53).

The curved shape of the U-shaped fortification platform is not formally defined in the text by Lucuze. In some of the engineers' plans, the graphic representation of the

Fig. 3 a The U-shaped layout shown in (Lucuze 1772: Fig. 53. Lam IV); b Fort of Sachal in Ceuta, by Don Luis Huet, 1763. Image: España, Miniesterio de Educación y Deporte, Archivo General de Simancas, ES.47161.AGS/4.3//MPD, 64, 033. Reproduced by permission
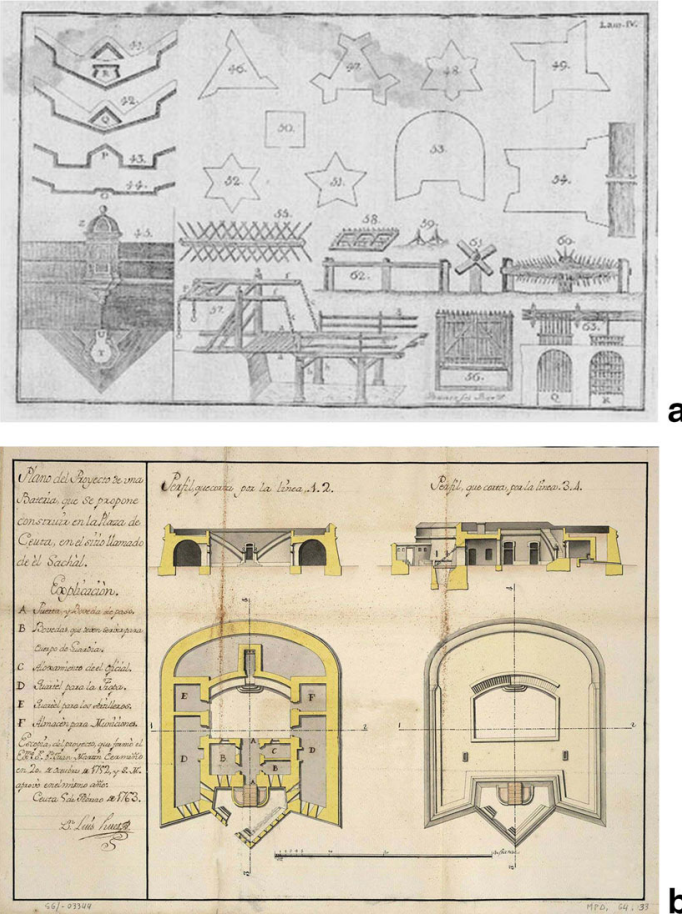
Fig. 4 a Composition of various plates from (Dürer 1527: p.23 bis and p.37 bis);

b example of the use of curved shapes, from (González de Medina Barba 1599: p. 176-177)

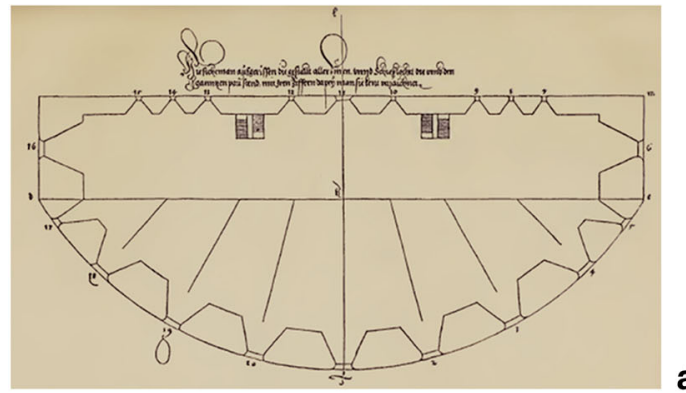

a
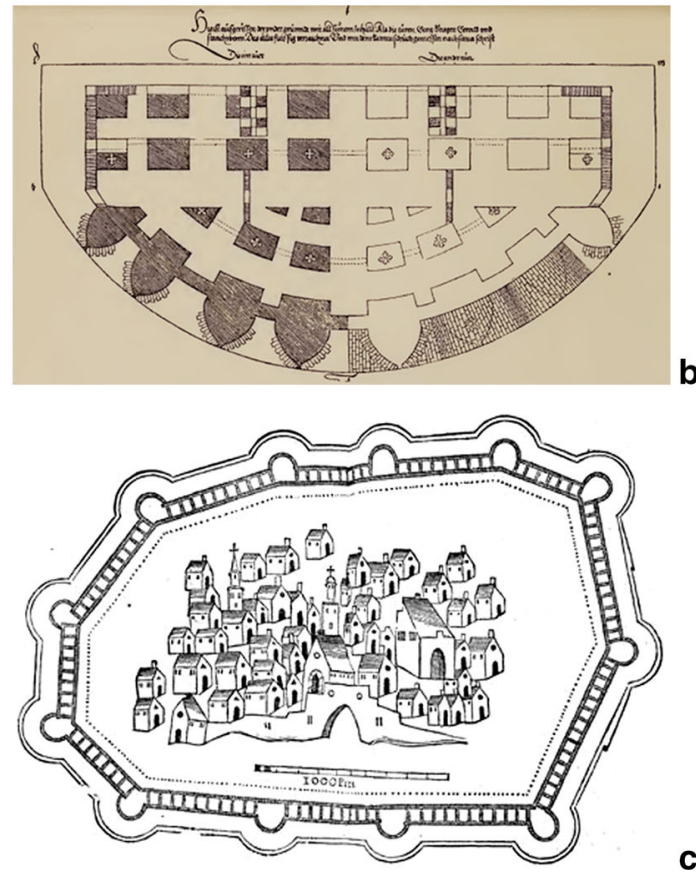

curved shape simply consists of an arc of circumference which is not even on a tangent to the flank. This type originates in the works of Albert Dürer (1471-1528), Etliche underricht zu befestigung der Stett, Schlosz, und flecken (1527), in the Geschützrondellen, rotundas with artillery, and the Pastey, a term for a bastion. To understand the U-shaped defensive arrangement, an obligatory reference is Chap. 5, 'Creating the powder artillery defense platform' (Dürer 1527) (Fig. 4a).

Curved shapes are very rarely used in military treatises, and limited to small defences. These include those by Diego González de Medina Barba (González de Medina Barba 1599: 200) (Fig. 4b), Gabrio Busca (c. 1540-1605) with semicircular elements (Busca 1601: 224), Jean Errard Bar-le-Duc (1554-1610) (Errard de Bar-leDuc 1604: 109-130), and those of the fortress and Castle of Lecco (Chafrión 1687: 31-32). 
Fig. 5 Batteries: a San Jorge de Alfama, c.1744. Image: SHM (9250); b Los Alfaques, 1779. Image: España, Miniesterio de Educación y Deporte, Archivo General de Simancas, ES.47161.AGS/4.3//MPD, 08, 130. Reproduced by permission

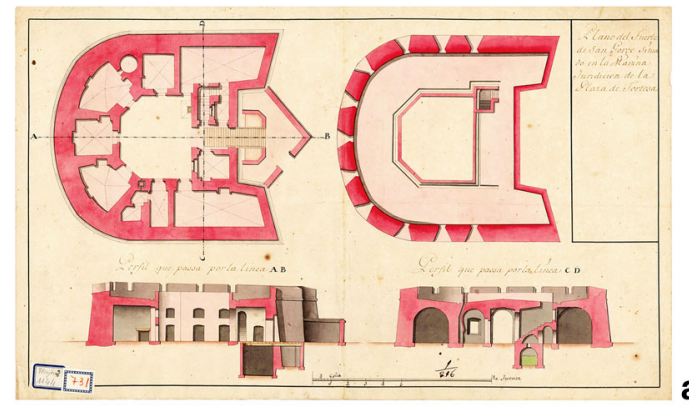

a

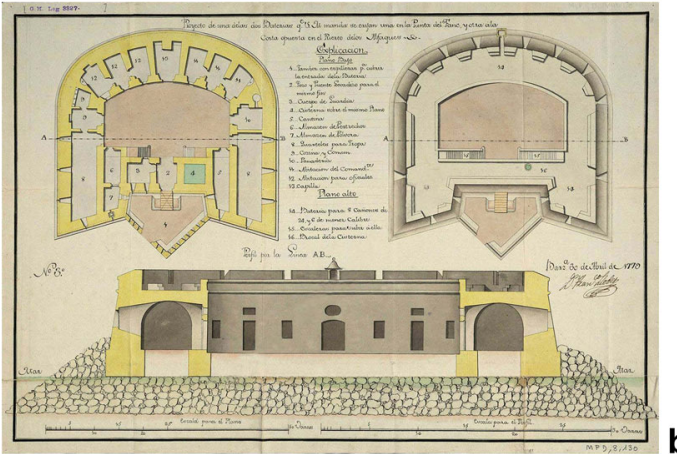

\section{The Eighteenth-Century Defences on the Coast of Tortosa}

Shortly after the surrender of the city of Tortosa to the Duke of Orleans, on 15 July 1708, during the War of Spanish Succession (1701-1713), Philip V (1683-1746) appointed Jorge Prosper Verboom (1667-1744) as General Engineer on 13 January 1710. During the siege of the city of Barcelona (1712-1714), Alejandro de Retz, holder of the high rank in Flanders, was sent to Tortosa in 1712 and appointed Director of the Catalan fortresses based in the city. One of the engineers' tasks was to construct batteries on the coast. The first stages saw the construction of the fort of Coll de Balaguer in around 1721, by the engineer Luis de Langot, Vauban's assistant, followed by the Fort of Sant Jorge (c. 1744), and the defences of San Carlos de la Rapita by Miguel Marin (1733), the defences of Puerto de los Alfaques, with the tower of San Juan (1739) by Enrique Legallois de Grimarest, and Marcos de Serstevens (1748), in Alcanar. In the second stage of fortification of the new city of San Carlos de la Rápita, Francisco Llobet (1779) planned similar types of fortification in the Alfaques area (Fig. 5b).

Various documents are available from the design and construction of the fort of San Jorge, in c. 1744. ${ }^{1}$ The layout of the project (Fig. 5a) was expressed in

\footnotetext{
${ }^{1}$ The documents in SHM (9250) include: "Plano del puerto de San Jorge, situado en la marina. Jurisdicción de la plaza de Tortosa" and "Plano del Fuerte de San Jorge" by López Sopeña (1740); "Plano y perfil del repuesto de pólvora del Fuerte de San Jorge a la plaza de Tortosa" and "Plano del Fuerte destacado de San Jorge en Tarragona" probably made by Marcos Serstevens (1750); and "Plano del Fuerte de San Jorge en la costa del gobierno de Tortosa y el último que se encuentra yendo hacia Barcelona” by López Sopeña (1772).
} 
Fig. 6 Oval and ellipse, Fort of Sant Jorge de Alfama, c.1744. Image: SHM (9250) with authors' geometric overlay, dimensions $\mathrm{P}$ given in pies. Reproduced by permission
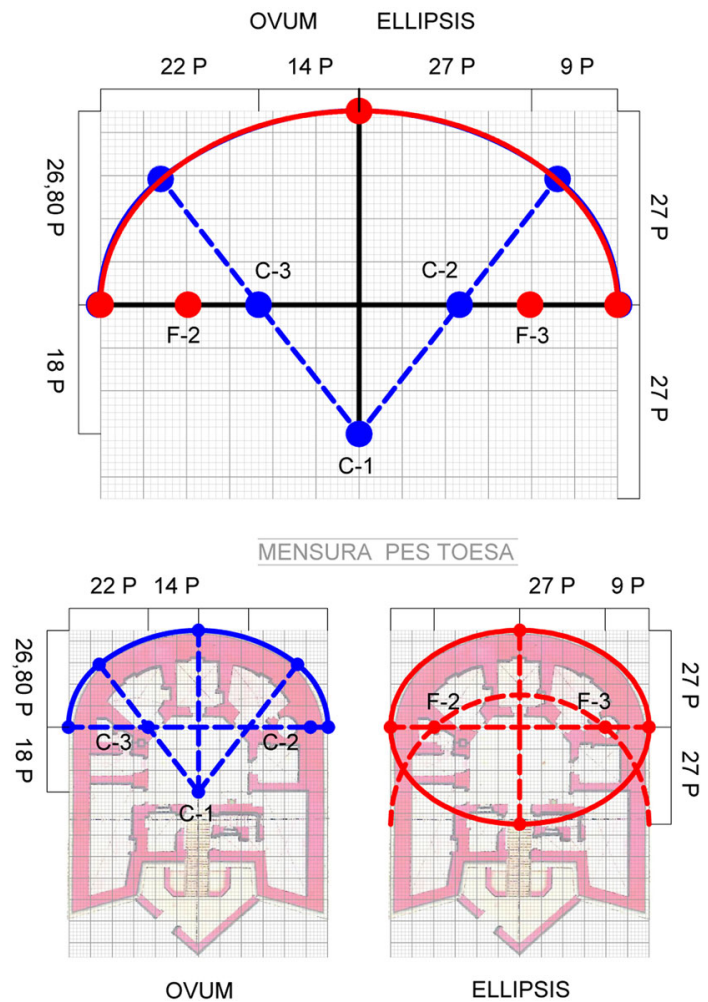

toesas and was performed using an oval, with the axis set at 12 toesas. The minor radius is 22 pies and the centre of the major radius is 18 feet from the axis, so that the oval is inscribed in a rectangle of $72 \times 26.8$ pies $(12 \times 4.46$ toesas). The metrological design of the ellipse would allow a rectangle of $72 \times 27$ pies, with a focus located 9 pies from the axis of the fortification (Fig. 6).

A manual planimetric survey of the Fort of San Jorge was conducted in 1984, with a maximum deviation of $1 \%$ (Generalitat 1990: 24) (Fig. 7). The metrology of the fortification's main walls and its measurements of width and height were seen to follow the metric of toesas. The measure of the front axis was 12.046 toesas $(23.49 \mathrm{~m})$ by 4.456 toesas $(8.69 \mathrm{~m})$. With these methods, and having a header with a metrology of 12 toesas and 4.5 toesas, there was a tendency to assume that the battery that was laid out by an ellipse with major axes of 12 and 4.5 toesas. The commensurability of the measure led to a manual delineation of the battery layout using the so-called gardener's or string method (see the "Appendix I: The Precedents for the Ellipse and the Conic Sections in the Literature" below), for which it was necessary to construct an ellipsograph. 

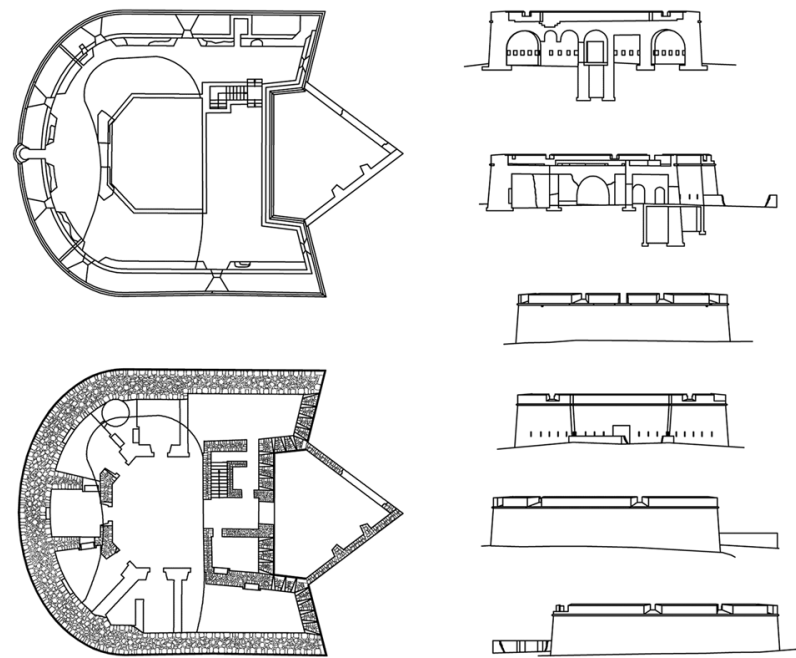

Fig. 7 Fort of San Jorge de Alfama. Image: Josep Lluis i Ginovart, 1984

The plan by Francisco Llobet (1705-1785) for Los Alfaques (1779), which was never built, is shown in a plan on paper, in coloured ink, measuring $53 \times 37 \mathrm{~cm}^{2}$ The document contains two orthogonal projections of the ground plans: "Explicación, Plano bajo..." (Explanation, ground floor) containing thirteen rooms and "Plano alto..." (Upper floor) with another three, and the "Perfil A-B" (orthogonal cross-section A-B). The scale used for the plan shows 50 Spanish varas $(19.6 \mathrm{~cm}$, about 1:220), while the scale used for the cross-section is 30 Spanish varas $(23.3 \mathrm{~cm}$, about 1:110). The design has a ground plan layout with a metrological base of a width of 46 varas, constructed by means of an oval (Fig. 8). The major axis is 15 varas from the head of the counterguard, the minor radius is 9 varas from the central axis, the major axis is 16 varas from that, and the rise is 16 varas and 1.5 palmos. If the plan is laid out on the ground with a precise metrology of $43 \times 47$ varas, the ellipse of $46 \times 32$ varas would have a focus located at about 5 varas from the axis of the fortification.

\section{The Metrological Foundations of Batteries}

The distinction between laying out the oval and the ellipse, in the construction of U-shaped bastions arises from the need for the geometric layout of the plan and its subsequent transfer to the work. In some cases semicircles were used for the delineation of bastions, as at Las Aguilas, 1752 (Fig. 9a), and in other cases arcs of circumference were used, as in Marbella, 1737 (Fig. 9b), but in most cases, as in Marbella, 1732 (Fig. 9c), ovals were used.

\footnotetext{
2 "Proyecto de una de las dos baterías que S. M. manda se erijan una en la punta del Franc y otra a la costa opuesta en el puerto de los Alfaques" (AGS, Secretary of War, Legajos, 03327). It was signed by Francisco Llovet, in Barcelona on April 30, 1779 (AGS: MPD, 08, 130).
} 
Fig. 8 Oval and ellipse of the Forts of Los Alfaques (1779) $(\mathrm{P}=$ pies). Image: España, Miniesterio de Educación y Deporte, Archivo General de Simancas, ES.47161.AGS/4.3// MPD, 08, 130, with geometric overlay by the authors. Reproduced by permission
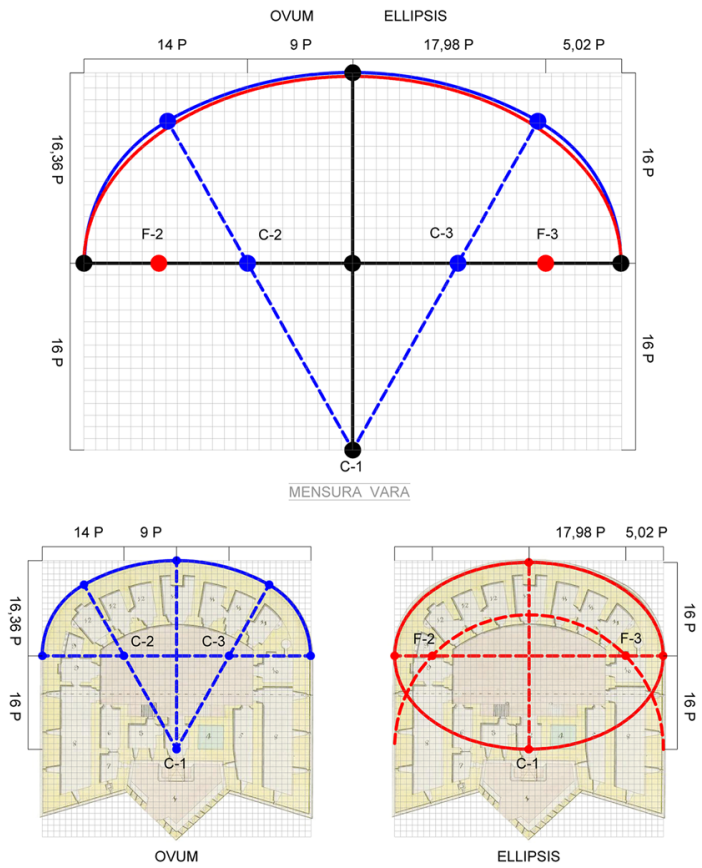

Different strategies for the layout of ovals can be found in the plans of Salobreña, 1722 (AGS: MPD, 59, 032); Marbella, 1732 (AGS: MPD, 39, 065); Campo de Gibraltar, 1750 (AGS: MPD, 56, 038); and los Alfaques, 1779 (AGS: MPD, 08, 130). In some cases, the ovals' major axis was divided into three equal parts, in others it was performed a metrological solution, and in other cases the layout is similar to the basket arch layout. The main drawback of this type of oval is that it is difficult to translate into the construction work, as it is necessary to perform several operations in order to lay out the centers.

The translation of the U-shaped work depended on two basic issues: (1) the ease of its layout and (2) the level of commensurability of the gauge of the U. If the dimensions of the axes are commensurable, it can be solved by the construction of either the ellipse or of the oval. The construction of the ellipse, using string, attributed to Anthemius of Tralles (c. 474-c. 558), was described by Cataneo (1567) and Bachot (1587). The design of the ellipse in the work is immediate. With the two axes, the foci are determined and the ellipse is laid out continuously, unlike the oval, in which the centre has to be changed. The foci require a compass operation at the end of the minor axis on the major axis of the battery. The difficulty with the figure lies in the construction of concentric ellipses, equidistant from main edges, as the focus changes position on the major axis.

One of the most influential figures in the theoretical training of Spanish military engineers, Tomás Vicente Tosca i Mascó (1651-1723) (Camara 2005: 133-158), provided instructions for constructing the oval when two axes are given (Tosca $\mathrm{i}$ Mascó 1707: I, prop. XV). The apparent difficulty of tracing the oval posed by the 

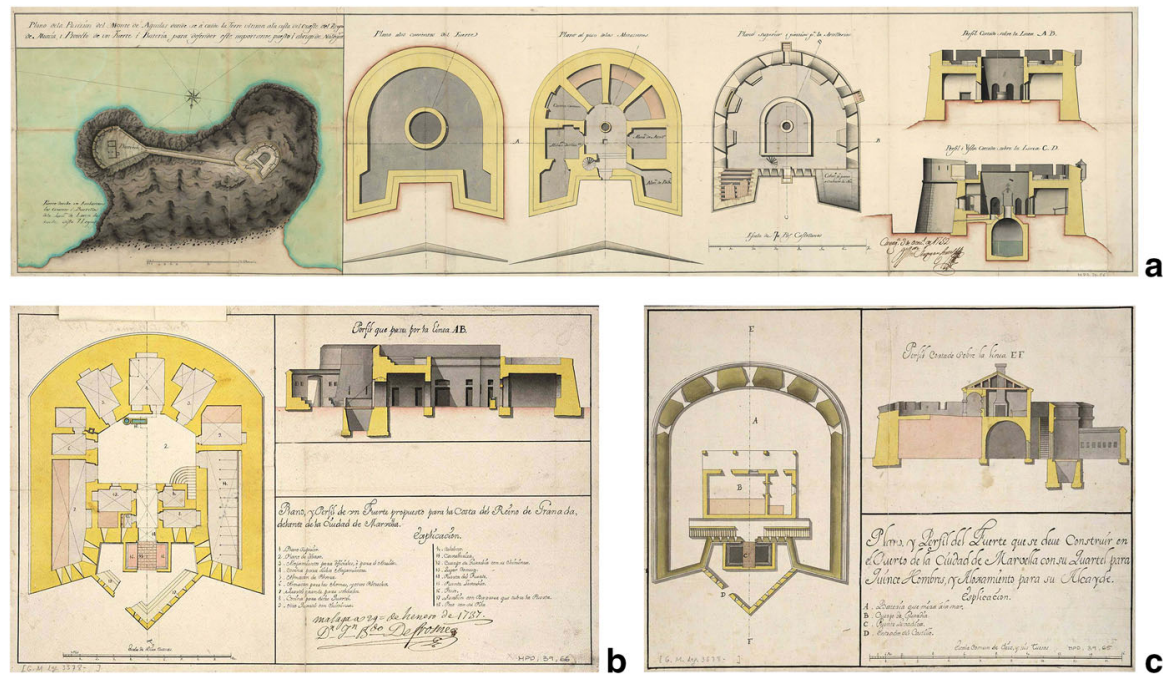

Fig. 9 Geometrical elevations: a Semicircumference at Las Aguilas, 1752. Image: España, Miniesterio de Educación y Deporte, Archivo General de Simancas, ES.47161.AGS/4.3//MPD, 20, 056; b arcs of circumference Marbella, 1737. Image: España, Miniesterio de Educación y Deporte, Archivo General de Simancas, ES.47161.AGS/4.3//MPD, 39, 066); c oval at Marbella, 1732. Image: España, Miniesterio de Educación y Deporte, Archivo General de Simancas, ES.47161.AGS/4.3//MPD, 39,065. Reproduced by permission

suppression of measures to find the centres was alleviated by his method. The tracing initially placed the centre of the minor arc on the major axis. This first measurement could be perfectly metrological, while the second centre of the oval, located on the minor axis, can be constructed by a simple squaring operation.

Unlike the laying out of the work, the delineation of a plan with concentric ellipses is complex, since, although various instruments were known, such as those described in Besson (1569), Barrozzi (1586) and Bachot (1587), the engineers used the two-pointed compass for its layout. The military engineers thus tended to use the oval (Fig. 10), using methods derived from Serlio (1545). With this method, the military engineer uses the width of the bastion as the major axis, and determines the minor axis using the layout method. The rise of the $U$ has a dimension which is derived and is therefore not measurable.

\section{Conclusion}

The geometric study of the plans of the U-shaped batteries of San Jorge and Los Alfaques concludes that they are laid out using Serlio's methods for ovals and their derivatives. The small-scale delineation of the platforms uses concentric ovals with two centers, as shown by the pin pricks in the paper left by the compasses used by the engineers.

The tracing of the $U$ shape of the Fort of San Jorge on the ground was very different. If the pre-established dimensions - those on the main axes-are taken as 

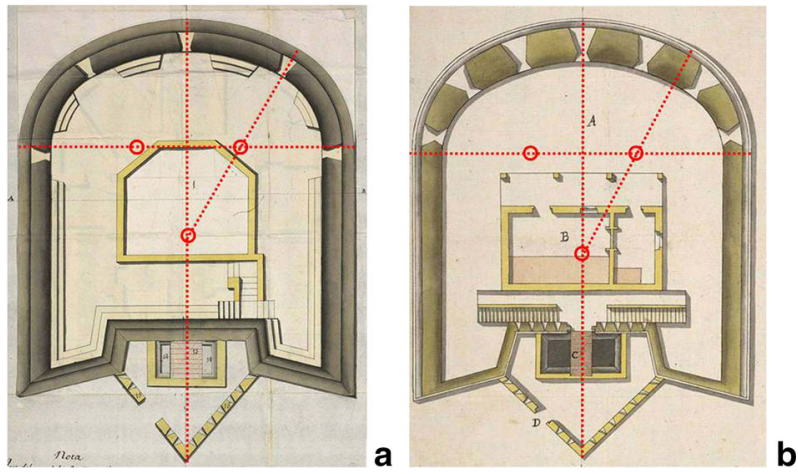

Fig. 10 Oval layouts: a Salobreña, 1722. Image: España, Miniesterio de Educación y Deporte, Archivo General de Simancas, ES.47161.AGS/4.3//MPD, 59, 032; b Marbella, 1732. Image: España, Miniesterio de Educación y Deporte, Archivo General de Simancas, ES.47161.AGS/4.3//MPD, 39, 065, with authors' geometric overlay. Reproduced by permission

the starting point, the geometric forms for laying out ellipses based on Cataneo (1567), and ovals based on Tosca i Mascó (1707) tend to be very similar (Fig. 11).

Both represent a similar degree of difficulty in the layout on the ground. Two geometric operations must be performed in order to lay out the wall of the " $U$ " using an ellipse, and thereby determine the foci of the concentric ellipses. If this is done using a Tosca oval, the centre of the minor radius is set on the major axis, meaning that two geometric operations are also required in order to lay out the other centre. The difficulty in laying out the ellipse and the oval for staking on the ground is very similar.

If we construct an ellipse and an oval with an area equivalent to $320.70 \mathrm{~m}^{2}$, for the Fort of San Jorge, with axes of 23.49 and $17.38 \mathrm{~m}$, the equivalent oval has the centre of the minor radius located $7.12 \mathrm{~m}$ from the flank of the Fort. The theoretical point is located $3.00 \mathrm{~cm}$ from the wall of the courtyard of the Fort.

An extraordinary approximation of both figures is obtained with the construction of the Tosca oval for San Jorge, and by placing a centre of the radius on the alignment of the courtyard wall. In fact, if the two perimeters are compared, in the flanks area, the oval tends to the extrados surface of the ellipse, with a difference of $6.02 \mathrm{~cm}$. Meanwhile, in the central area of the perimeter, the oval tends towards the intrados of the ellipse, with a difference of $4.09 \mathrm{~cm}$. The order of measurement is close to the margin of error of $1 \%$ established in the survey of the Fort carried out in 1984. At that time it was determined that the perimeter was laid out by an ellipse. After the new studies, the Tosca oval equivalent, which has a minor radius located on the wall of the central courtyard, allows us to hypothesize this second solution, with the perimeter laid out using an oval.

Although the equations in the figures are mathematically very different, the formal parameterization of the tracing of the U-shaped battery of San Jorge, could be both an oval and an ellipse. The margin of error in any tracing for both figures can be perfectly absorbed in both hypotheses. 


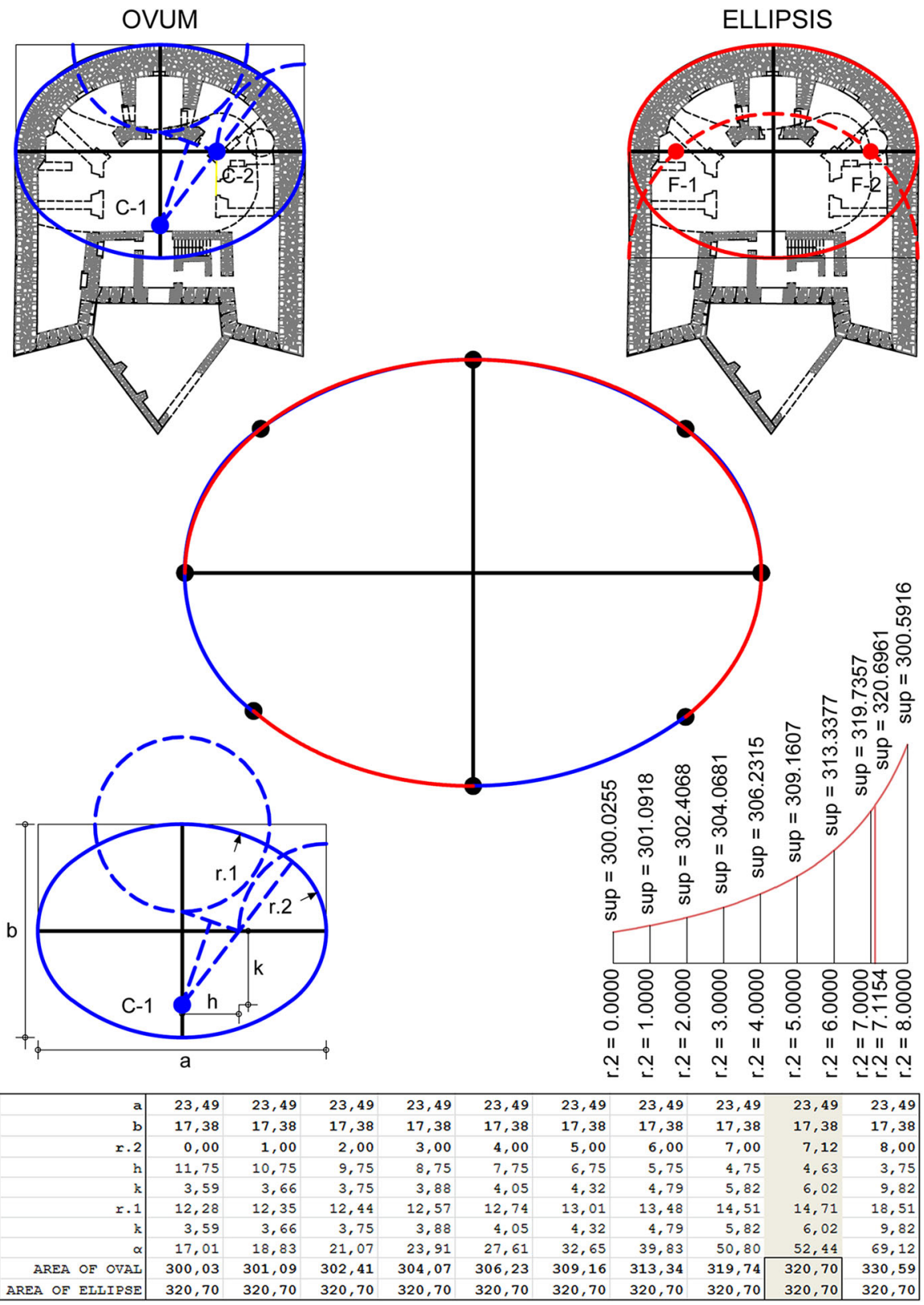

Fig. 11 Layout of the equivalent oval and ellipse at the Fort of San Jorge. Image: authors

There is a fundamental difference between the two figures, derived from the science of optics of the Enlightenment. The two figures are very different in terms of receiving impact and disrupting the thrust of the projectile. If the impact is 
perpendicular during the descent of the parabola, the disruption of the oval figure tends to be univectorial, passing through any of the three centres of the oval. In the ellipse, the impact tends to decompose into two vectors passing through the foci located on the major axis.

\section{Appendix I: the Precedents for the Ellipse and the Conic Sections in the Literature}

The first study of the ellipse using conic sections is attributed to Menaechmus (c. 380-c. 320 BC) (Heath 1896: xvii-xxx). The ellipse was determined in various ways: as the section of the cone, by Archimedes of Syracuse (c. 287-212 BC) in Conoids and Spheroids (IV-VI) and by Apollonius of Perga (c. 247-205 BC) in Conics (Book I, VII-IX); as the oblique section of a right cylinder whose directrix is a circle, by Pappus of Alexandria (c. 290-c. 350) in the Collection (Book VIII, P 13-17).

During the Quattrocento, the great libraries belonging to Basilios Bessarion (1403-1472), Pope Nicholas V (1397-1455), Giorgio Valla (1447-1501), Filippo de Ser Ugolino (d. 1435) and Federico da Montefeltro (1422-1482) contained many codices by Archimedes, Apollonius and Pappus (Rose 1973). In 1501 Valla, who owned Codex $A$ by Archimedes and Pappus, published De expetendis et fugiendis rebús (Things to Seek and to Avoid), in which he reconstructed Nicomedes' compass (Fig. 12a), published in later editions of Archimedes.

The first treatise on conic sections in the Renaissance was produced by Johannes Werner (1468-1528) in 1522 (Super Vigintiduobvs Elementis Conicis ...), with the publication of some instruments attributed to Plato as well as the compass of Nicomedes (in Definitio V). His reconstruction differs from Valla's (Fig. 12b).

Mathematics was the basis for a rediscovery of the classics. In 1537 Giambattista Memo (d. 1537) was responsible for the editio princeps of Apollonius, with the first four books of the Conics; the second edition was by Federico Commandino (1509-1575). In about 1560 Francesco Maurolico (1494-1575) attempted to reconstruct the fifth and sixth books, which were available in Greek, in his Fifth and Sixth Elementorum conicorum (finally published as Emendatio et restitutio conicorum Apollonii Pergaei in 1654). The Arabic translation of books V-VII of Abraham Echellensis (d. 1664), culminated in the 1661 publication of the edition by Giacomo Alfonso Borelli. Finally, the eighth book was restored by Edmund Halley (1656-1742) in 1706, based on the introductory lemmas by Pappus. Archimedes' work was edited by Johann Gechauff (Venatorius, d. 1551), with a first edition in 1544 and a second edition by Federico Commandino in 1558, whose work on Pappus was published posthumously in 1588, thanks to his student Guidobaldo del Monte (1545-1607).

In astronomy, studies of cosmology led to an interest in conics. Nicholas Copernicus (1473-1543), in his 1543 De Revolutionibus Orbium Coelestium, uses the concept of the Tusi couple to resolve a linear movement in the sum of two circular motions of a circle of one radius within a circle with a radius double that of the first. This concept originated in the commentary on the Almagest, Tahrir al- 

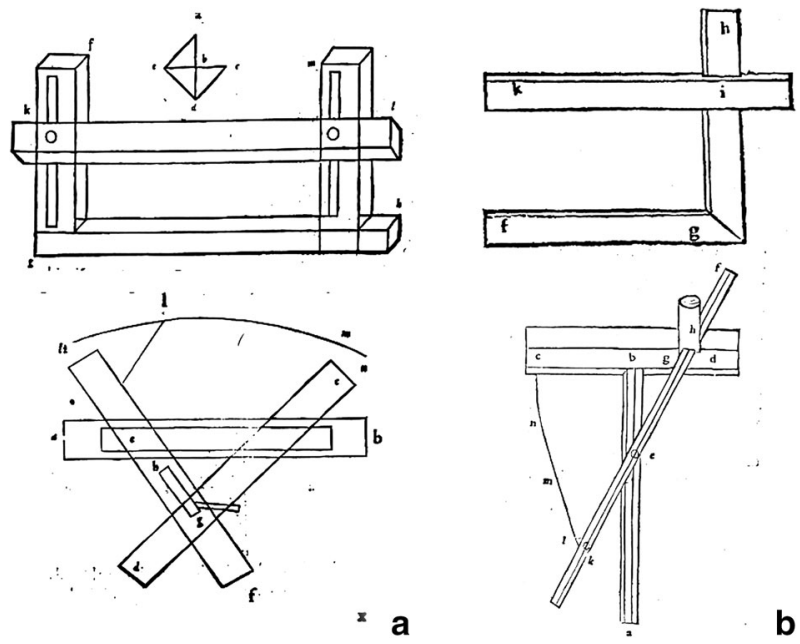

Fig. 12 Instrumentation attributed to Plato and Nicomedes: a reconstructed by Valla, 1501; b as reconstructed by Werner, 1522

Majisti (1247) by Nasir al-Din al-Tusi (1201-1274). Copernicus considered the question in Book III, ch. 4 (fols. 67r-v), which he used to draw an ellipse (Fig. 13a). With regard to the optical part of astromony, Johannes Kepler (1571-1630), in "The Metrological Foundations of Batteries", De Coni Sectionibus, of the 1604 Ad Vitellionem Paralipomena, identifies five types of sections: the circumference, ellipse, parabola, hyperbola and line (Fig. 13b). Any conic can be obtained from the other (pp. 92-109).

In the field of optics, Claude Mydorge (1585-1647) greatly simplified the tests of Apollonius in his books of 1631 and 1639, Prodromi catoptricorum et dioptricorum, which provided the geometrical basis for optics; he later published, in 1644, De sectionibus conicis. René Descartes (1596-1650), in his 1637 Discours de la méthode, edited the Dioptrique (Fig. 14a, b), which deals with conics in the eighth discourse. During the same period, he devoted part of the second book of the Geometrie to curved lines (Fig. 14c, d), and the instruments needed for drawing them.

Seventeenth-century mathematics made further contributions to conics. Blaise Pascal (1623-1662), in Theorem Mysticum Hexagrammum (1639), published 2 years later as a pamphlet, Essay pour les coniques, established that if a hexagon is inscribed within a cone and its opposite sides are projected beyond the section, the three points where they meet will be on a straight line. The synthesis of the instrumental layout of conics using the concept of congruence was developed by Frans van Schooten (1615-1660) in his Organica Conicarum Sectionum in Plano Descriptione of 1646 (Fig. 15). Van Schooten also published, in 1649, the Latin version of Descartes's Geometrie. This was followed by a new edition in 1659 with Johan de Witt (1629-1672), Johan Hudde (1629-1704) and Hendrick Van Heuraet 

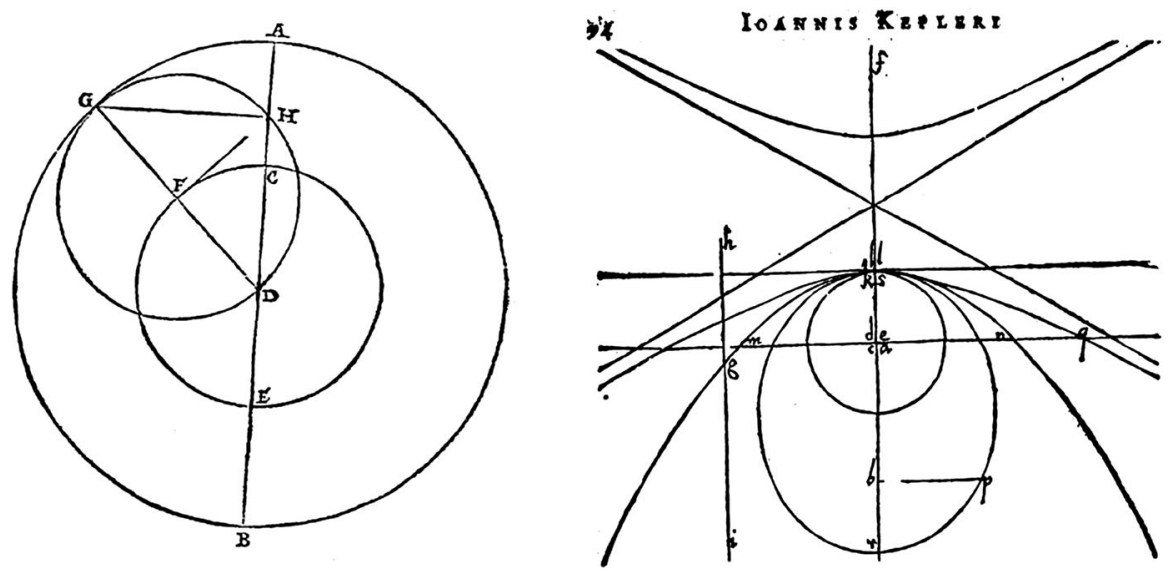

Fig. 13 a The Tusi couple shown in the De Revolutionibus Orbium Coelestium by Copernicus (figure from p. 67r); b conic sections from Kepler's 1604 Ad Vitellionem Paralipomena (figure from p. 94)
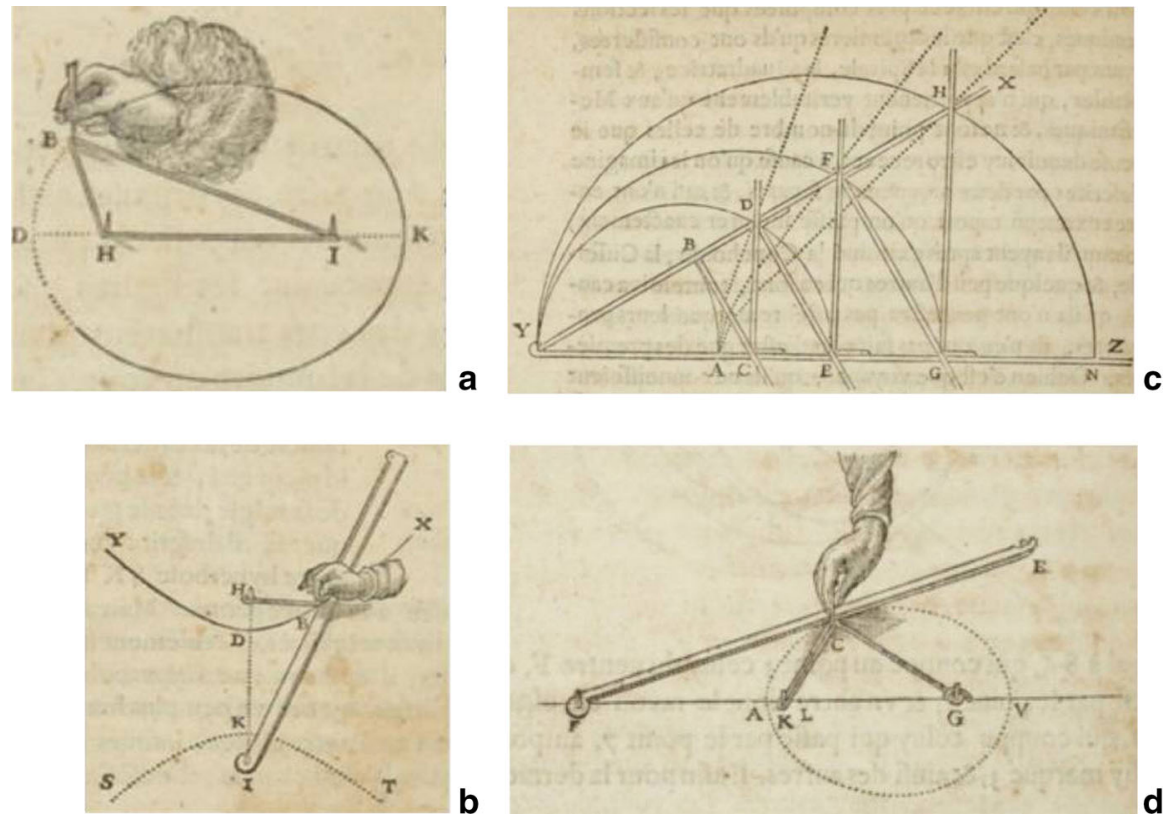

Fig. 14 Images of conic sections in the 1637 work of Descartes: a, b Dioptrique (figures on pp. 90 and 102); c, d Geometrie (figures on pp. 318 and 356)

(1633-1660), with commentary by Witt, Elementa Curvarum Linearum and a second edition in 1661 .

Other complementary treatises include the 1655 De sectionibus conicis nova expositis by John Wallis (1616-1703), which deals with curves using the Cartesian 
method derived from their properties based on the definition of the plane, and the 1685 Sectiones conicae by Philippe de la Hire (1640-1719), which deduces the properties of cones based on the projection of a circle. These works consider the reflective context of conics based on the discipline of mathematics.

\section{Appendix II: Background to the Tracing of Conics}

The approach to conic sections, and especially the ellipse and the parabola, which were constructed using forms with various centres, was well known in the ancient world and the late classical era. Vaults were built in Egyptian architecture, anse de panier surhaussée, and laid out using three centres (Choisy 1904: 45-46). According to (Blume et al. 1848: 91-107), the gromatici, or agrimensores, appear to have constructed ex pluribus circulis forma sine angulo using several centres of circumference, as shown in the Expositio et ratio omnium formarum by Balbus (Balbus mensor?, c.100). The Roman surveying strument known as a groma can be used to trace the ellipse and the oval, and could have been the basis for setting out the Colosseum (Docci and Migliari 2001: 13-24).

In Book I.1 De aedificis (561), Procopius of Caesarea (c. 490-565) emphasizes the knowledge of the ellipse's reflective properties of Anthemius of Tralles (c. 474c. 558), who built the Hagia Sophia. Anthemius, in his treatise $\Pi \varepsilon \rho \hat{\imath} \pi \alpha \rho \alpha \delta \delta \xi \omega v$ $\mu \eta \chi \alpha \nu \eta \mu \alpha \tau \omega \nu$ (Concerning wondrous machines) (Huxley 1959: 6-19) considers questions related to the tangent of the ellipse, using its foci and its bisector. The construction of an ellipse by a string or chain, fixed by the foci, is attributed to him (Heath 1931: 518-519).

During the Renaissance, there was considerable interest in the construction of instruments capable of laying out conic figures (Rose 1970: 371-404). The origin of the perfect compass has traditionally been attributed to the circle around Leonardo da Vinci (1452-1519) and Albert Dürer (1471-1528), as a result of the transmission and influence of Giorgio Valla and Johannes Werner. Leonardo depicted the compasso parabolico in the Codex Leicester fol. 108r (c.1494); in the Codex Atlanticus (fol. 1093r) (c. 1513-1514) he drew the prospettografo; he drew the perfect compass in the Codex Atlanticus [fol. 5r((c. 1480-1482))] (Pedretti 1999: 44-49); he showed how to construct the mechanical ellissografo in Ms I Madrid (fol. 24r) (Kurz 1960: 15-24). In his 1525 Underweysung der Messung mit dem Zirckel und Richtscheyt Albert Dürer (1471-1528) determined the sections of the cone (Bk I, 34-37), and the construction of an oval (Bk I, 33), defining it as shaped like a well-formed egg (Bk I, 22) (Herz-Fischler 1990: 75-85; Huerta 2007: 224). He describes an instrument for the layout of curves with the displacement of the lancet inclined (Bk I, 39) along two perpendicular axes (Dürer 1525).

Of particular interest is the necessary coincidence between the perfect compass, al-birkâr al-tâmm, by Abû Salh al-Qûhî (c. 922-c. 1000) (Rashed 2003) (Fig. 16a) and that of Francesco Barozzi (1537-1604) (Fig. 16b), given in his 1586 Admirandum illud geometricum (Raynaud 2007: 299-345). In Barozzi's introduction (pp. 10-31), he discusses the usefulness of the design of conics for Mechanics and Architecture, using the perfect compass. The range of Theatrum 

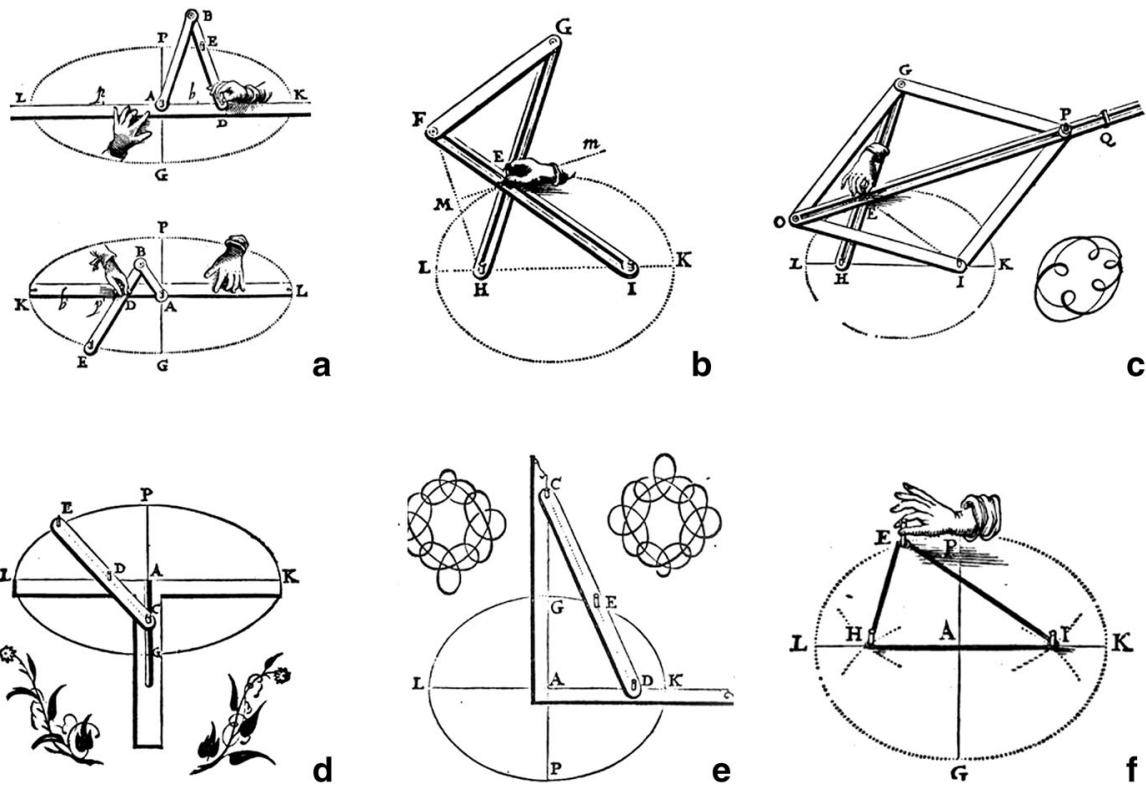

Fig. 15 Van Schooten's instruments: a, b, c (figures from Organica: a p.26, b p.50, c p.52); and classical systems for the layout of ellipses: d, e, f (figures from Organica: d p.28, e p.30, f p.31)

instrumentorum was very successful in the second half of the sixteenth century, as in those derived from Jacques Besson (1540-1573) with the Circinus novus et universalis (Pl. 5) (Besson 1569: fol 5r).

\section{The Non-Commensurable Oval in the Treatises}

Despite knowledge of conic sections and the perfect compass, in the discipline of architecture there was a tendency to approximate the ellipse using the figure of the oval (López Mozo 2009: 265-272; Gentil 1996: 78-84), by laying out the compass in the Gothic tradition. The main sources appear in treatises on civil and military architecture and in the extensive range of practical geometries. In this present study, we do not consider constructions derived from stereotomy, the construction of diminished arches or vaults, and oval domes (Huerta 2007: 211-248; López Mozo 2011: 569-597), due to the large difference in scale compared to the kind of constructions analyzed.

Three types of different curved elevations can be defined in both the treatises on civil and military architecture and the major practical geometries, although there are few etymological differences between most of the authors. We will differentiate between the layout of ellipses and ovals. Ovals can be divided into those that are known as incommensurable, since by establishing one axis, the other can be deduced; and those that are traced based on the two main axes, the measurements of which may be the same as the axes of the ellipses. 

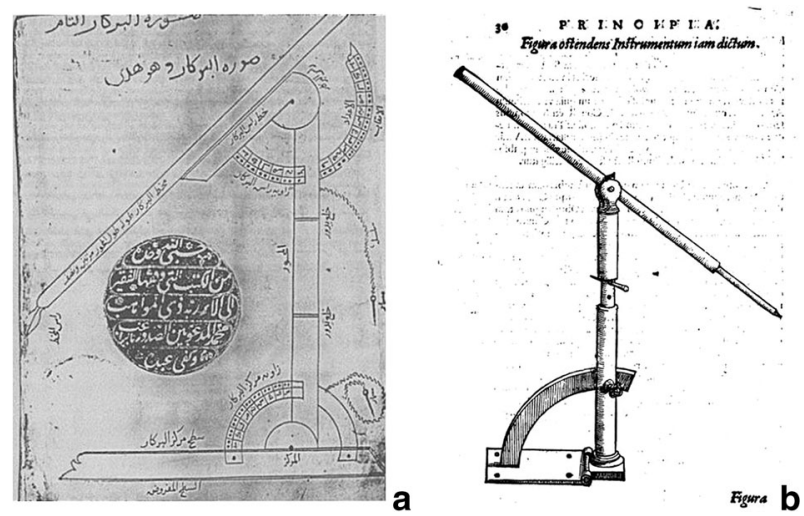

Fig. 16 Perfect compass; a as shown by Raghib Pasha 569, Istanbul (fol. 235v); b as shown by Francesco Barozzi, 1586, fol. 30

Based on the induction of classical knowledge, Sebastiano Serlio (1475-1554) attempted to lay out the oval in Il Primo libro d'architettura. He identified four ways to trace the oval: the first one, based on the triangle, a second one from three circles, another from two perfect squares and finally another with the use of two circles with touching centers (Serlio 1545: fol. 17v-18v; Serlio 1551: fol. 13r-13v). The constructions parameterized the major axis, and the minor axis was deduced from this (Rosin 2001: 58-69). This could only initially define the major axis of the oval.

Serlio's influence on architectural treatises increased. Des Zirckels und Richtscheyts are reproduced in the Vitruvius Teutsch by Walter Hermenius Ryff (c. 1500-1548) (Fig. 17a). In Spain, they are reproduced in a different order in the manuscript (c. 1545-1562) by Hernán Ruiz the Younger, (c. 1514-1569) (Navascués 1974, Lam. XXIV) (Fig. 17b) and in De varia commensuración para la Esculptura y Architectura (1585) by Juan de Arfe y Villafañe (1535-1603), Trata de Ovalos y como se forman, contains seven figures (Arfe 1585: B.I.Chap. III). The Serlian layout model was still in use in the seventeenth century, in L'idea dell'architettura universale by Vincenzo Bertotti Scamozzi (1548-1616) (Bertotti Scamozzi 1615: Bk II, ch. VII, pp. 119-123) and in the Arte y Uso de Architectura of Fray Lorenzo de San Nicolás (1595-1679) (San Nicolás 1639: Ch. LXXVIII, 149v-152r). In the Compendio de arquitectura y simetría de los templos, Simón García considers calculating the area (García 1681: fols. 89r-89v), and Dürer's plotting of the oval (García 1681: fol. 77v).

Serlio was widely read among the engineers of the Cinquecento. Niccoló Tartaglia (1499-1577) (1560), in La Quinta parte del General Trattato de numeri et misure, considered the oval in Chap. VII; he considered the ellipse in definitione (Fig. 17c), although he did not use Book VI of the Quesiti, et inventioni diverse de Nicolo Tartalea for these geometries, and decided on the triangle (Tartaglia 1554: 64r-77v). Simon Stevin (1548-1620) considered the oval in Problemata geometrica of the Tomus Secundus Mathematicorvm Hypomnematvm (Stevin 1605: Bk. I, prop. 


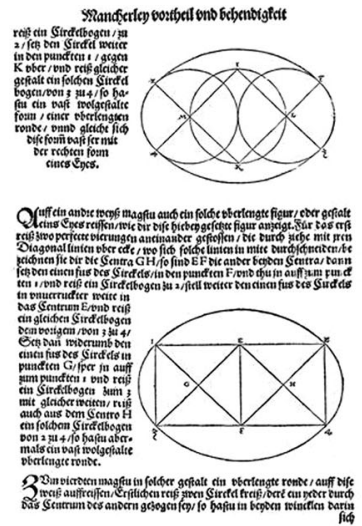

a

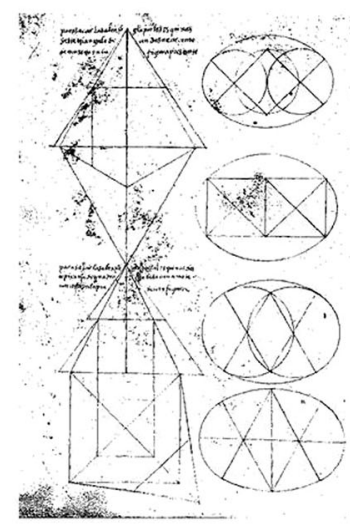

b

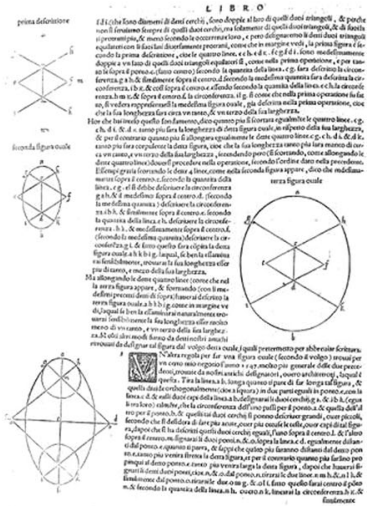

C

Fig. 17 The transmission of Serlio's methods of constructing the oval: a by Walter Ryff (1548: XXIrXXIIr); b by Hernán Ruiz the Younger (c.1545-1569) (Navascués 1974, Lam. XXIV); c by Niccolò Tartaglia (1560: 11r-12v)

9), but he did not use it in the De Sterctenbouwing (Stevin 1594), which was limited to polygonal shapes. In Spain, Cristóbal Rojas (1555-1614) did not mention the layout of the oval, but used it in the stereotomy of the basket arch (Rojas 1598: Par III. Chap. VIII, 98).

The Serlian model was still used in military engineering in the seventeenth century. This is true of the Corona imperiale dell'architettura militare by Pietro Sardi (1618: 81-83). Alonso Cepeda y Adrada, in Chapter XVI of the Epítome de la fortificación moderna, uses the method of creating oval figures (Cepeda 1669: 36-37, Print 6 Figs. 13, 14, 15). Sebastián Fernández de Medrano (1646-1705), in Rudimentos geometricos y militares describes 'an oval around two squares formed on a line' the calculation of their area (Fernández 1677: 19, 34-35).

\section{The Layout of the Ellipse in the Treatises}

Pietro Cataneo (d.1569) considered the oval in L'architettura [1567: Book VII, Props. XII, XIII and XIV). In Prop. XIV (Cataneo 1567: 157-158), he mentions tracing an oval using the string method, but he is in fact tracing an ellipse, and is able to determine the measurements of the two main axes. In Le Timon du Capitaine [a work that was reprinted and completed and came to be known as Le Gouvernail (Bachot 1598)] Ambroise Bachot (d.1587) considered the continuous layout of the elliptic with string, and the invention of a tool for the delineation of ellipses (Bachot 1587: Figs. 20, 21) (Fig. 18a). These methods require a string with a minimum length that is equal to the major axis for the layout of the ellipse. The figures were examined by Buonaiuto Lorini (1540-1611) in the introduction to Book I in Delle fortificationi (Lorini 1596: 6), and the addition to the sixth book, for the defence of the fortress (Lorini 1609: 6) (Fig. 18b). In Regla y modo para conseguir la medida 

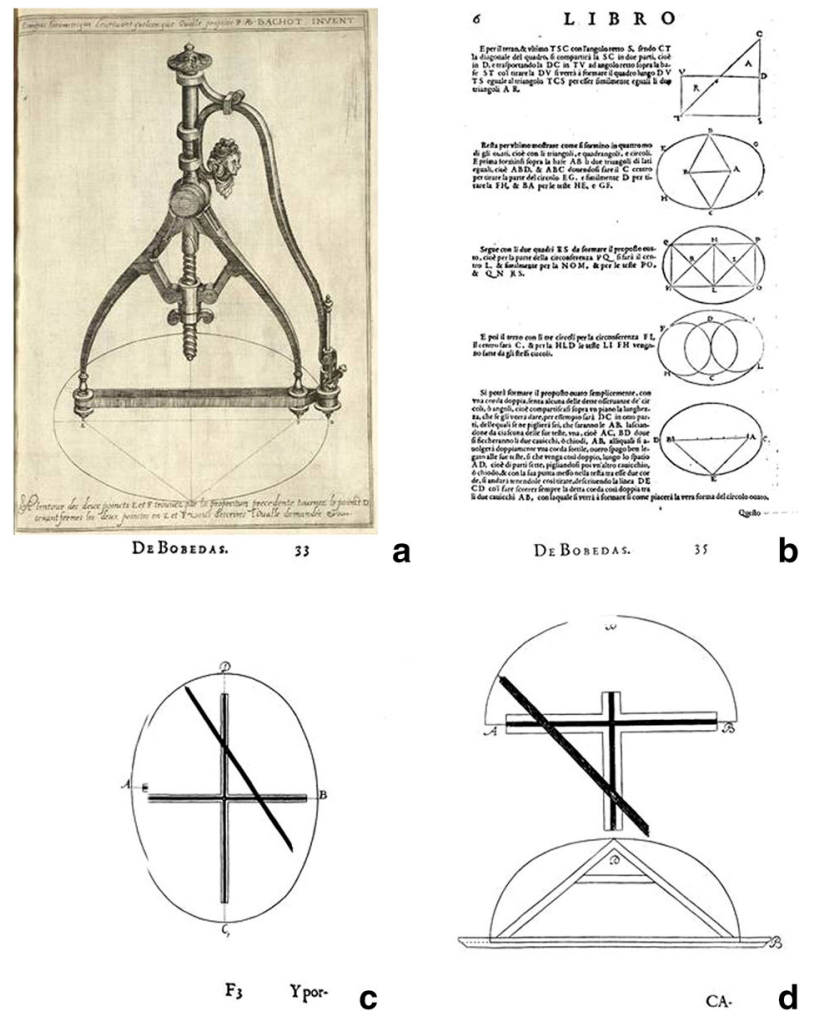

Fig. 18 a Ellipsograph by Ambroise Bachot (1587, 1598); b oval and ellipse by Lorini (1596, 1609); c, d Tool for tracing an ellipse, by Juan de Torrija (1661, c p.33; d p.35)

irregular de las Bobedas... Juan de Torrija (1624-1666) also constructs a tool for tracing the ellipse (Torrija 1661: 33r-35r), although he makes no distinction between the oval and the ellipse (Fig. 18c, d).

The construction of ellipses by transferring the middle of their foci through their main axes is shown in Plate 13 of Traité des pratiques geometrales et perspectives by Abraham Bosse (1602-1676) (Fig. 19a) and in Pratique de la géometrie, by Sébastien Le Clerc (1637-1714) (Fig. 19b). The method is not continuous, determines points of the curve, and involves using a string half as long as the minor axis. Constructions of the ellipse using string were widespread until the editions of the fortification by Sébastien Le Prestre de Vauban (1633-1707) (Abbe Du Fay 1691: 10).

\section{The Commensurable Oval in the Eighteenth Century Treatises}

Fray Tomás Vicente Tosca i Mascó (1651-1723) dedicated Volume III of the Compendio mathematico (1710) to Conic Sections: In Book I he determines various 

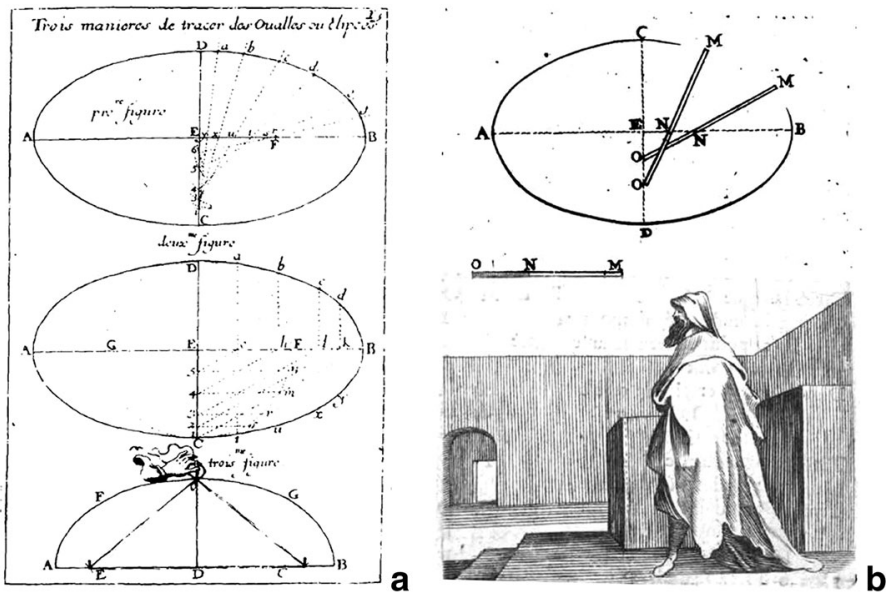

Fig. 19 Ellipse using the minor axis: a Abraham Bosse (1665: 63); b Sébastien Le Clerc (1669: Book II, Prop. XIII, 54-55)
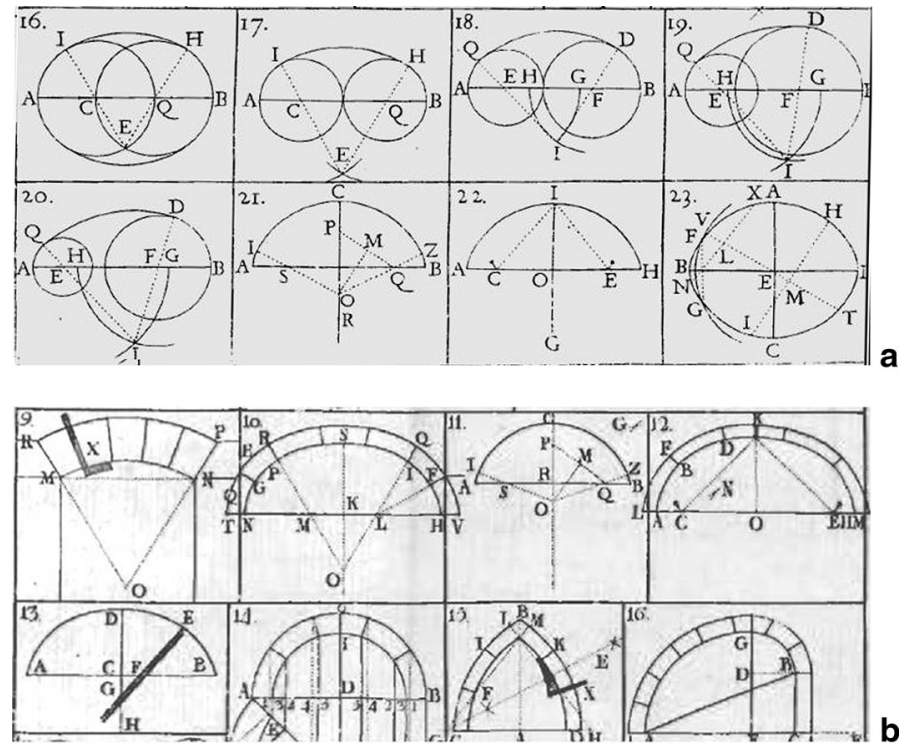

Fig. 20 a solutions for ovals when the main axes are established (Tosca i Mascó 1707: fol. 296, Print 2); b different ways of laying out diminished arches (Tosca i Mascó 1712: fol. 110, Print 8)

designs De la elypse (Tosca i Mascó 1710, 163-198). Previously, in Volume I (1707) he had considered the oval (Treatise III, Book II, De la Geometría Práctica, Prop. XIV-XVII), in which (Prop. XV) he examined infinite solutions for ovals by establishing the main axes (Tosca i Mascó 1707, 292-295) (Fig. 20a). The solution was disseminated in Volume $\mathrm{V}$ of the Compendio, which was devoted to civil and 

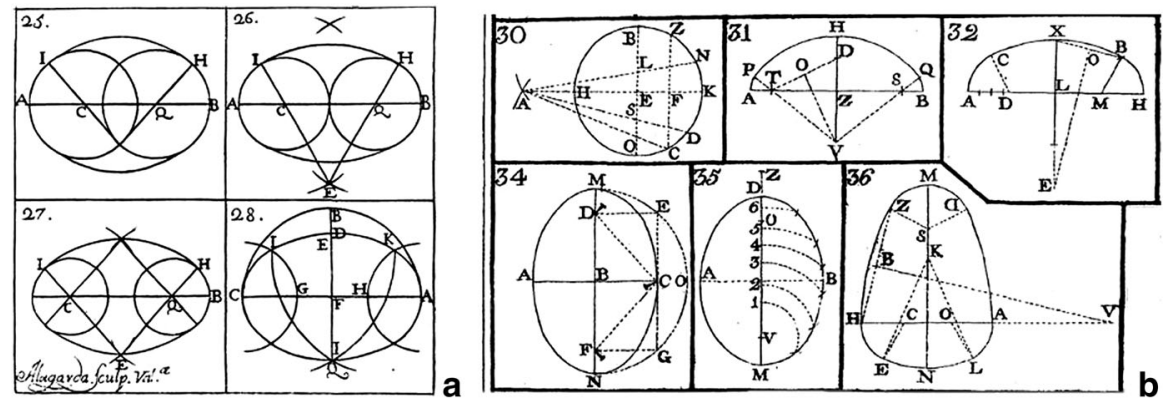

Fig. 21 Geometric ways of constructing ovals: a from Brizguz y Bru (1738: Estampa 4 Fol 17. Figure 25, 26, 27 i 28); $\mathbf{b}$ from Plo Camin (1767: Estampa 2 Libro I, Fol 92. Figures 30, 31, 32, 33, 34, 35 i 36)
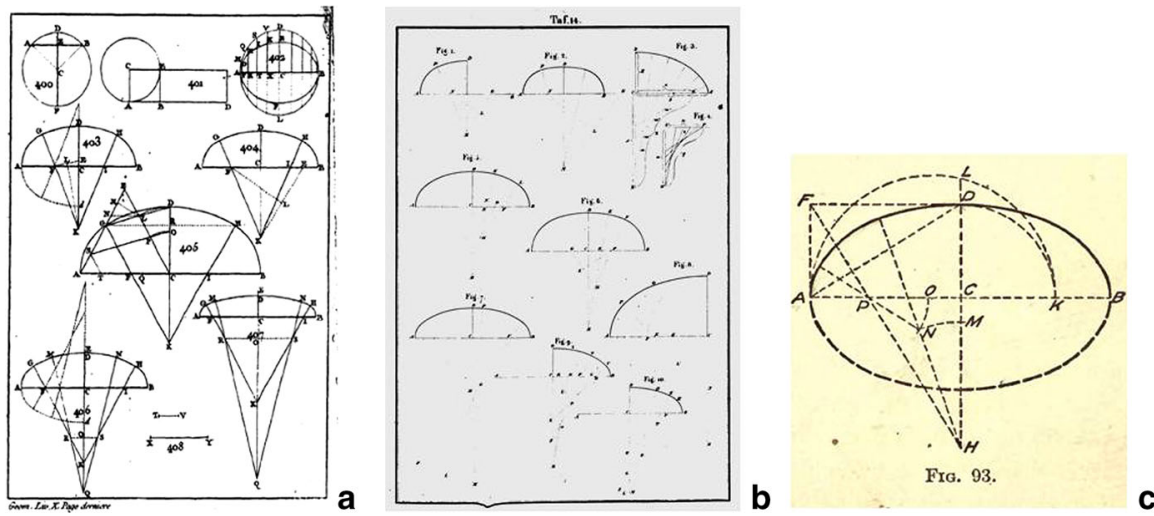

Fig. 22 Oval with eight centres: a from Camus (1750: Figs. 406 and 407, p.536 bis); b from Breymann (1849: 41-42 taf. 14); c from French (1911: 53, Fig. 93)

military architecture, applied to the different ways of laying out the diminished arch (Tosca i Mascó 1712: Book II Prop. III, 99-104). The method makes the elevations of the oval commensurable, and able to be laid out in such a way that they pass through the axes of the ellipse (Fig. 20b).

Similar methods subsequently became widespread. These included the one by Jean-Baptiste De La Rue (1728: 5, Figs. 6, 7). A similar method was published by Agustín Bruno Zaragoza y Ebrí in his treatise on architecture (Brizguz y Bru 1738: 16-17). Amédée François Frézier (1682-1773) considered the stereotomy of the ellipse using the Compas à Ovale (Fig. 117) and continuous movement (Fig. 118), with the instruments of Frans van Schooten (Frézier 1737: I, 129-148, Pl. 10 Fig. 110-118). He dedicated one proposition to the construction of an oval through the main axes (Frézier 1737: 183, Pl. 153). Paolo Federico Bianchi (d. 1766) proposed a method with the same geometrical structure as De La Rue (1728) and Atanasio Genaro Brizguz y Bru (1738) (Fig. 21a) (Bianchi 1766: 33-36, Fig. 8). Antonio Plo Camin (d.1767), determined six ways of completing ovals (Plo Camin 
1767), two of which involved establishing the axes, one of which was that of Tosca $i$ Mascó (1707), and a variation of Bianchi (1766) (Plo Camin 1767, 70-78) (Fig. 21b).

Further contributions to tracing the oval included the eight-centre method by Charles-Étienne-Louis Camus (1699-1768) Des anses de Panier, determining the construction d'une anse a Panier à cinq centres, shown in Figs. 406 and 407 there [Camus 1750: Bk. X, Ch.. II, 526-536] (Fig. 22a). Other methods were mentioned in treatises on construction such as the one by Gustav Adolf Breymann (1807-1859) (Fig. 22b), and the treatises on industrial design by Thomas Ewing French (1871-1944) (Fig. 22c). The debate on the different methods of approximating the oval and the ellipse continued until well into the twentieth century [Bradshaw 1917: 301-302].

\section{References}

Abbe Du Fay. 1691. Maniere de fortificante: Selon La Methode De Monsieur De Vauban. Avec un Traite des préliminaire. Paris: Coignard.

Arfe, J. 1585. De varia commensuración para la Esculptura y Architectura. Sevilla: Andrea Pescioni y Juan de León.

Bachot, A. 1587. Le Timon du Capitaine Ab. Bachot, Lequel conduira le lecteur Parmi les guerrières ... Paris: Au faubourg Saint-Germain-des-Prés.

Bachot, A. 1598. Le Gouvernail d'Ambroise Bachot, capitaine ingenieur du Roy... Melun: Imprime l'auteur soubz; et aussi s'en trouuera Son en Logis à Paris.

Barrozzi, F. 1586. Admirandum illud geometricum problema tredecim modis demonstratum, quo docet duas lineas ... Venitiis, Apud Gratiosum Perchacinum.

Bertotti Scamozzi, V. 1615. L'idea dell'architettura universale di Vinsenzo Scanmozzi architetto véneto divisa in X libri. Venezia: Expenssis Auctore.

Besson, J. 1569. Instrumentorum et machinarum Quas Jacobus Bessonus Delphinas mathematicus et un machinis practer otras cosas excogitavit... s.l. s.n. s.d.

Bianchi, P.F. 1766. Instituzione pratica dell 'Architettura Civile per la decorazione de' pubblici, e privati edifici...2 vols. Milano: Gianbattista Bianchi.

Blume, F., K. Lachmann, and A. Rudorff. 1848. Die Schriften der römischen Feldmesser, vol. I. Berlin: Bei Georg Reimer.

Bosse, A. 1665. Traité des pratiques geometrales et perspectives: enseignées dans l'Academie royale de la peinture et sculpture. Paris: Chez l'Auteur en l'Ille du Palais.

Bradshaw, J.W. 1917. Approximate Construction for an Ellipse. The American Mathematical Monthly 24(6): 301-302.

Busca, G. 1601. Della Architettura militare di Gabriello Busca. Milano: Girolamo Bordoni.

Breymann, G.A. 1849. Allgemeine Bau-Constructions-Lehre, mit besonderer Beziehung auf das Hochbauwesen..., vol. 1. Stuttgart: Hoffmann.

Brizguz y Bru, A.G. 1738. Escuela de Arquitectura civil, en que se contienen los ordenes de Arquitectura, la distribución... Valencia: Oficina de Joseph Thomas Lucas.

Camara, A. 2005. La arquitectura militar del padre Tosca y la formación teórica de los ingenieros entre Austrías y Borbones. In Ingenieros militares de la Monrquía Hispánica en los siglos XVII y XVIII, ed. A. Cámara. Madrid: Ministerio de Defensa.

Camus, M. 1750. Elémens de géométrie théorique et pratique (Cours de mathématique, Seconde Partie). Paris: Durand.

Cataneo, P. 1567. L'architettura di Pietro Cataneo senese: oltre alla quale todos essere stati dall'istesso autore riuisti,... Venice: Aldus.

Cepeda, A. 1669. Epítome de la fortificación moderna. Asii en lo regular, como en lo irregular, reducida a la regla,... Brussels: Por Francisco Foppens. 
Chafrión, J. 1687. Plantas de las fortificaciones de las ciudades, plazas y castillos del Estado de Milan. S.1 : s.n., s.a.

Chafrión J. 1693. Escuela de Palas o Cursos Mathemáticas. Milan: En la Emprente Real por Marcos Antonio Pandulpho Malatesta.

Choisy, A. 1904. L'art de bâtir chez les égyptiens. Paris: E. Rouveyre.

Davila, A. 1672?. Plazas fortificadas en el Ducado que era de Lorena, con un tratado de geometría practica para traçar figuras regulares... Madrid?: s.n.

De La Rue, J.B. 1728. Traité de la coupe des pierres où, par une méthode facile \& abrégée, l'on peut aisément se perfectionner en cette... Paris : De l'Imprimerie royale.

De Villegas, E.D. 1651. Academia de fortificación de plazas y nuevo modo de fortificar una plaza real. Madrid: Alonso de Paredes.

Docci, M., Migliari, R. 2001. Architettura e geometria nel Colosseo di Roma. Pp. 13-24 in Matematica e architettura. Metodi analitici, metodi geometrici e rappresentazioni in architettura. Firenze: Alinea editrice. Università di Firenze. Fac. Architettura.

Dürer, A. 1525. Unterweysung der Messung, mit dem Zirckel und Richtscheyt: in Linien Ebnen vo gantzen Corporen. Nürenberg: Hieronymum Formschneyder.

Dürer, A. 1527. Etliche underricht zu befestigung der Stett, Schlosz, und flecken. Nürenberg: Hieronymus Andreae.

Errard de Bar-le-Duc, J. 1604. Fortification demonstree et reduicte en art par I. Errard de Bar-le-Duc. Paris: s.n.

Fernández, S. 1677. Rudimentos geométricos y militares que propone... Sebastian Fernandez de Medrano. Bruselas: Viuda Vleugart.

French, T. 1911. Manual of Engineering Drawing for Students and Draftsmen. New York: McGraw-Hill Book Co.

Frézier, A.F. 1737. La théorie et la pratique de la Coupe des Pierres. La theorie et la pratique de la coupe des pierres ... Tome premier. Strasbourg: J.D. Doulksseker le fils.

García, S. 1681. Compendio de Architectura y Simetría de los templos conforme a la medida del cuerpo humano con algunas demostraciones de geometría. Tratados de Arquitectura y Urbanismo: Serie V. vol.13. Colección Clásicos Tavera. Madrid: Fundación Histórica Tavera.

Generalitat, C. 1990. Catàleg de Monuments i Conjunts Històrico-Artístics de Catalunya. Barcelona: Departament de Cultura.

Gentil, J. M. 1996. La traza oval y la sala capitular de la catedral de Sevilla. Una aproximación geométrica. In: Cuatro edificios sevillanos. Metodologías para su análisis. Sevilla: Demarcación de Sevilla del Colegio Oficial de Arquitectos de Andalucía Occidental.

González de Medina Barba, D. 1599. Examen de Fortificacion, hecho por Don Diego Gonçalez de Medina Barba... Madrid: En la Imprenta del Licenciado Varez.

Heath, T.L. 1896. Apollonius of Perga Treatise on conic sections. Edited in modern notation with introductions including an essay. Cambridge: At the University Press.

Heath, T.L. 1931. A Manual of Greek Mathematics. Oxford: Clarendon Press.

Herz-Fischler, R. 1990. Durer's Paradox or Why an Ellipse Is Not Egg-Shaped. Mathematics Magazine 63(2): 75-85.

Huerta, S. 2007. Oval Domes: history. Geometry and Mechanics. Nexus Network Journal 9(2): 211-248.

Huxley, G.L. 1959. Anthemius of Tralles. A Study in Later Greek Geometry. Cambridge: Printed by the Eaton Press.

Kurz, O. 1960. Dürer. In Leonardo and the invention of the ellipsograph, 15-24. Raccolta Vinciana; Archivio Storico del Commune di Milano, 18.

Le Clerc, S. 1669. Pratique de la géometrie, sur le papier et sur le terrain. Paris: Thomas Jolly.

León, F. 1992. Arquitectura y Matemáticas según los tratados españoles del siglo XVIII. Implicaciones sociológicas. Anales del Seminario de Metafisica, 767-780. Núm. Extra. Homenaje a S. Rábade.

López Mozo, A. 2009. Bóvedas de piedra en el Monasterio de El Escorial. Ph.D. Thesis, Escuela Técnica Superior de Arquitectura, Universidad Politécnica de Madrid.

López Mozo, A. 2011. Ovals for any given proportion in architecture: a layout possibly known in the sixteenth century. Nexus Network Journal 13(3): 569-597.

Lorini, B. 1596. Delle fortificationi di Buonaiuto Lorini libri cinque: ne' quali si mostra con le piu facili regole la scienza con la pratica, ...Venice: Gio. Antonio Rampazetto.

Lorini, B. 1609. Le di fortificationi Buonaiuto Lorini nobile Fiorentino nuovamente ristampate,... con l'aggiunta del Libro sesto. Venice: Francesco Presso Rampazetto. 
Lucuze, P. 1772. Principios de fortificación, que contienen las definiciones de los terminos principales de las obras.... Barcelona: Thomas Piferrer.

Lucuze, P. 1773. Disertacion sobre las medidas militares que contiene la razón de preferir el uso de las nacionales al de las forasteras. Barcelona: Por Francisco Suría y Burgada.

Migliari, R. 1995. Ellissi e ovali. Epilogo di un conflitto. Palladio 16(8): 93-102.

Navascués, P. 1974. El libro de arquitectura de Hernan Ruiz, el Joven. Madrid: Escuela Tecnica Superior de Arquitectura de Madrid.

Pedretti, C. 1999. Leonardo. Le macchine. Firenze: Giunti Gruppo Editoriale.

Plo Camin, A. 1767. El Arquitecto práctico, Civil, Militar y Agrimensor, dividido en tres libros....Madrid: En la Imprenta de Pantaleon Aznar.

Rashed, R. 2003. Al-Qûhî et al-Sijzî: sur le compas parfait et le traće continu des sections coniques. Arabic Sciences and Philosophy 13: 9-43.

Raynaud, D. 2007. Le tracé continu des sections coniques à la Renaissance: applications opticoperspectives, héritage de la tradition mathématique arabe. En. Arabic Sciences and Philosophy 17: 299-345.

Rojas, C. 1598. Teoría y Práctica de fortificación, conforme las medidas y defensas de los tiempos, repartida en tres partes... Madrid: Por Luis Sanchez.

Rose, P.L. 1970. Renaissance Italian methods of drawing the ellipse and related curves. Physis 12: 371-404.

Rose, P.L. 1973. Humanist Culture and Renaissance Mathematics: the Italian Libraries of the Quattrocento. Studies in the Renaissance 20: 46-105.

Rosin, P.L. 2001. On Serlio's Constructions of Ovals. The Mathematical Intelligencer 23(1): 58-69.

Ryff, W.H. 1548. Vitruvius Teutsch: Nemlichen des aller namhafftigisten vn[d] hocherfarnesten, Römischen Architecti, und Kunstreichen Werck oder Bawmeisters, Marci Vitruuij Pollionis, Zehen Bücher von der Architectur vnd künstlichem BawendEin Schlüssel vnd einleytung aller Mathematische[n]. Nürnberg: Johan Petreius.

San Nicolás, L. 1639. Arte y Uso de Architectura. Dirigida al Smo. Patriarca S. Iosepb. Compuesto por Fr. Laurencio de S Nicolas, Agustino Descalço, Maestro de Obras S.l : s.n., s.a.

Sardi, P. 1618. Corona imperiale dell'architettura militare di Pietro Sardi. Venice: Stampata dell'autore.

Serlio, S. 1545. Il Primo libro d'architettura di Sebastiano Serlio, bolognese. Le premier libre d'Architecture de Sebastiano Serlio, Bolognoi, mis en lange Francoyse par Iehan Martin. París: Jean Barbé.

Stevin, S. 1594. De Sterctenbouwing Besehreuen door. Leiden: By Françoys.

Stevin, S. 1605. Tomvs Secvndvs Mathematicorvm Hypomnematvm. Lvgodini Batavorvm: Patius.

Tartaglia, N. 1554. Quesiti, et inventioni diverse de Nicolo Tartalea Brisciano. Venetia: Venturino Rusinelli.

Tartaglia, N. 1560. La Quinta parte del General Trattato de numeri et misure di Nicolo Tartaglia. Venetia: Curtio Troiano.

Torrija, J. 1661. Breve tratado de todo genero de bobedas asi regulares como yrregulares execucion de obrarlas y medirlas... Madrid: Pablo de Val.

Tosca i Mascó, T. V. 1707. Compendio mathematico: Que comprehende Geometria elementar, arithmetica inferior, geometria practica... Tomo I. Valencia: Por Antonio Bordazar.

Tosca i Mascó, T. V. 1710. Compendio mathematico: Que comprehende Trigonometria, Secciones Conicas. Maquinaria Tomo III. Valencia: Por Antonio Bordazar.

Tosca i Mascó, T. V. 1712. Compendio mathematico: Que comprehende Arquitectura civil, montea, y canteria, arquitectura militar, pirotechnia, y artilleria. Tomo V. Valencia: Por Antonio Bordazar.

Josep Lluis i Ginovart graduated in Architecture from the Universitat Politècnica de Catalunya and holds a $\mathrm{PhD}$ from the Universitat Internacional de Catalunya. He is a professor of intervention in architectural heritage at the Universitat Rovira i Virgili (URV), as well as Magíster operis sedis Dertusae and Director of the Master Plan of Santa María de Tortosa Cathedral. His research focuses on medieval architecture and geometry from the point of view of historical construction.

Josep M. Toldrà Domingo graduated in Architecture from Universitat Politècnica de Catalunya (2000). Obtained a Master's degree in Classical Archaeology from Universitat Rovira i Virgili (2011), where at 
present teaches projects at the Architecture School at Reus. As an architect, has completed interventions in several historical buildings, including Roman structures and eighteenth century fortifications in the city of Tarragona. His research focuses on the application of photogrammetry and laser scanning to study the geometry of historical building.

Gerard Fortuny Anguera is an associate professor at the Universitat Rovira i Virgili (URV). He graduated in Mathematics from the Universitat de Barcelona and obtained $\mathrm{a} \mathrm{Ph}$ at the Universitat Politècnica de Catalunya. He is chair of the department of Architecture at URV. His research interests include the structural computation of historical buildings using the Finite Element Method, and the relationship between mathematics and architecture in historical buildings.

Agustí Costa Jover is a doctoral student at Universitat Rovira i Virgili (URV). He graduated in Architecture from the Universitat Politècnica de Catalunya (UPC), where he also completed a Master's degree in Architectural Rehabilitation and Restoration. His current research is focused on architectural heritage and the assessment of its structural and constructive properties.

Pau Sola-Morales graduated in architecture from ETSAB (1993), and obtained a Doctor of Design from Harvard University (2000). His research focuses on "architecture, information and complexity", linking architectural theory and the use and application of information technologies in design, on which he has written several articles. He has been visiting professor at the Harvard design School and the Accademia di Architettura, Mendrisio (USI), as well as in other international schools. At present he is professor of architectural theory and informatics at the Architecture School at Reus (URV). 